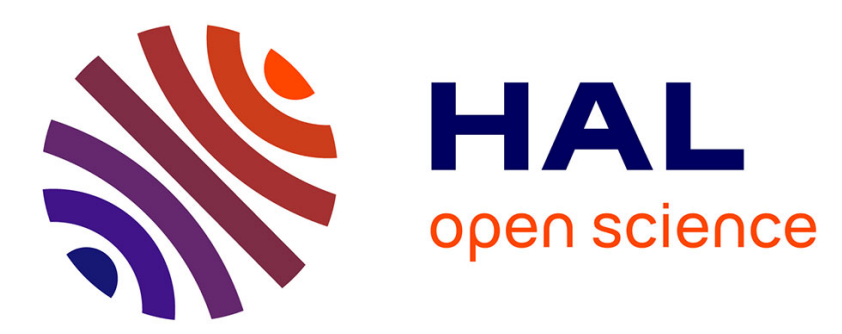

\title{
Influence of DNA repair gene variants in overall survival of non-small cell lung cancer patients treated with first line chemotherapy
}

\author{
Augusto Nogueira, Raquel Catarino, Ana Coelho, António Araújo, Mónica \\ Gomes, Rui Medeiros
}

\section{To cite this version:}

Augusto Nogueira, Raquel Catarino, Ana Coelho, António Araújo, Mónica Gomes, et al.. Influence of DNA repair gene variants in overall survival of non-small cell lung cancer patients treated with first line chemotherapy. Cancer Chemotherapy and Pharmacology, 2009, 66 (3), pp.501-506. 10.1007/s00280009-1187-2 . hal-00552480

\section{HAL Id: hal-00552480 \\ https://hal.science/hal-00552480}

Submitted on 6 Jan 2011

HAL is a multi-disciplinary open access archive for the deposit and dissemination of scientific research documents, whether they are published or not. The documents may come from teaching and research institutions in France or abroad, or from public or private research centers.
L'archive ouverte pluridisciplinaire HAL, est destinée au dépôt et à la diffusion de documents scientifiques de niveau recherche, publiés ou non, émanant des établissements d'enseignement et de recherche français ou étrangers, des laboratoires publics ou privés. 


\title{
Influence of DNA repair RAD51 gene variants in overall survival of non-small cell lung cancer patients treated with first line chemotherapy
}

\author{
Augusto Nogueira $\cdot$ Raquel Catarino $\cdot$ Ana Coelho $\cdot$ \\ António Araújo $\cdot$ Mónica Gomes $\cdot$ Rui Medeiros
}

Received: 13 September 2009 / Accepted: 11 November 2009 / Published online: 4 December 2009

(C) Springer-Verlag 2009

\begin{abstract}
Purpose Lung cancer continues to be the most frequent cancer with approximately one million people worldwide dying of this disease each year. Non-small-cell lung cancer (NSCLC) accounts for approximately $80 \%$ of all lung cancers. The RAD51 protein is the key protein for homologous recombination, an evolutionarily conserved mechanism for DNA damage repair and the generation of genetic diversity. We conducted this study in order to investigate the effect of the RAD51 G135C polymorphism in treatment response to combined platinum taxanes/gemcitabine first line chemotherapy in NSCLC patients.

Methods We analysed RAD51 G135C polymorphism in 243 NSCLC patients using PCR-RFLP methodology.

Results There were no statistically significant differences between the groups of NSCLC patients with the different genotypes regarding tumour stage $(p=0.232)$. Our results indicate that the mean survival rates were statistically different according to the patient's genotypes. The group of
\end{abstract}

A. Nogueira $\cdot$ R. Catarino $\cdot$ A. Coelho $\cdot$ M. Gomes .

R. Medeiros $(\square)$

Molecular Oncology Unit, Portuguese Institute of Oncology, Instituto Português de Oncologia, Laboratórios-Piso 4, R. Dr. Ant. Bernardino Almeida, 4200-072 Porto, Portugal e-mail: ruimedei@ipoporto.min-saude.pt

R. Catarino $\cdot$ R. Medeiros

ICBAS, Abel Salazar Institute for the Biomedical Sciences, Porto, Portugal

\section{A. Araújo}

Medical Oncology Department,

Portuguese Institute of Oncology, Porto, Portugal

R. Medeiros

Faculty of Health Sciences of Fernando Pessoa University, Porto, Portugal patients carrying the $\mathrm{C}$ allele presented a higher mean survival rate than the other patients (56.0 months vs. 41.7 months; $p=0.024$ ). Moreover, regarding smoking history, our results demonstrate that overall survival time differed significantly according to the patient's genotypes in smoker and ex-smoker individuals $(p=0.034)$. No statistically significant differences were found in the genotype frequencies and overall survival rate among non-smoker NSCLC patients $(p=0.413)$.

Conclusions This is the first study evaluating the effect of the RAD51 G135C polymorphism in NSCLC patient survival. Our results suggest that RAD51 genotypes could be useful molecular markers for predicting the clinical outcome of NSCLC patients.

Keywords RAD51 - Non-small cell lung cancer · DNA repair $\cdot$ Overall survival

\section{Introduction}

Lung cancer remains a major worldwide health problem, being the most common form of cancer in the world, both in terms of incidence, $12.3 \%$ of all cancers, and mortality, representing $17.8 \%$ of the number of deaths caused by cancer [18]. In Europe, each year more than 150,000 new cases are diagnosed, but only $10 \%$ can be cured and enjoy long-term survival, mostly because of advanced stage detection. The incidence of lung cancer is higher in men and in older individuals. However, during the past decade, the incidence of this disease in females has increased, due to the change of smoking habits in women $[1,19]$. While $90 \%$ of people with lung cancer have a smoking history, only $10-15 \%$ of chronic smokers develop lung cancer, suggesting factors in addition to smoking exposure are relevant 
in the aetiology of this disease [45]. Age, smoking exposure, impaired lung function and family history have been identified as independent risk factors for this disease [1].

There are two major groups of lung carcinomas: smallcell lung cancer (SCLC) and non-small cell lung cancer (NSCLC). Non-small cell lung cancer accounts for approximately $80 \%$ of all lung cancers and includes epidermoid (squamous cell) carcinoma (which accounts for $25-40 \%$ of all lung cancers), adenocarcinoma, undifferentiated nonsmall cell lung cancer and large cell carcinoma [15].

Lung carcinogenesis is a multi-step process of progressive disorganization characterized by events over latent periods of time, resulting from exposure to environmental insults [4].

Maintenance of genetic stability requires the co-ordination of a network of pathways such as cell cycle checkpoint, DNA replication, DNA repair/recombination and programmed cell death. In response to DNA damage, cells arrest their cell cycle progression, thus providing time for repair, or activate programmed cell death-both responses preventing transmission of genetic instability [21, 22]. Double-strand breaks (BSBs) are considered the principal lethal DNA damage [2]. There are two distinct mechanisms in damage repair of mammalian cells, such as homologous recombination (HR) and non-homologous end joining (NHEJ) [8].

The human RAD51 gene has a key role in the homologous recombination and DNA repair [33]. This gene is located at chromosome position $15 \mathrm{q} 15.1$ [38], a region that exhibits loss of heterozygosity in a large range of tumours, including lung, colorectal and breast cancers [43]. The protein (hRAD51) encoded by this gene is highly similar to Escherichia coli RecA and Saccharomyces cerevisiae RAD51 [20] and has been suggested to play a role as a tumour suppressor gene [33]. Several studies have reported that mutations in genes involved in DNA repair and in the maintenance of genome integrity may be responsible for an increase of cancer risk [34].

Homologous recombination (HR) effects DNA repair through the interaction of free DNA ends with a homologous DNA sequence that is used as a template for the highfidelity repair of the DSB. HR is thought to be particularly important in DNA repair occurring during cellular replication $[34,44,46]$. RAD51 is one of the key proteins for HR, and functions by forming nucleoprotein filaments on single-stranded DNA, mediating homologous pairing and strand exchange reactions between single- and doublestrand stranded DNA during repair [41].

A single nucleotide polymorphism (SNP) in the $5^{\prime}$ untranslated region (5'-UTR) of the human RAD51 gene, resulting in a $\mathrm{G}-\mathrm{C}$ substitution at nucleotide 135 of the non-coding exon 1 has been described and referred to as G135C polymorphism [24]. The genetic variants of G135C polymorphism have been associated with breast [7] and gastric cancers [30].

Our purpose was to investigate the potential prognostic and predictive roles of RAD51 G135C polymorphism in NSCLC patients treated with combined platinum taxanes/ gemcitabine first line chemotherapy.

\section{Materials and methods}

Patients

We conducted a hospital-based study analysing 234 Caucasian individuals from the north region of Portugal with NSCLC, admitted in the Portuguese Institute of Oncology, Porto, Portugal, between 1999 and 2008, who underwent first line platinum and taxanes/gemcitabine-based chemotherapy regimens. Assessment of the tumour stage was based on the TNM system proposed by the American Joint Committee on Cancer (AJCC). The median age at diagnosis was 64 years with a mean age of 62.44 years $(\mathrm{SD}=10.01)$. Patient clinical characteristics, obtained from medical records, are described in Table 1. Genomic DNA was extracted from blood samples by using QIAamp DNA Blood Mini Kit (QIAGEN). All samples were obtained with the informed consent of the participants prior to their inclusion in the study, according to the declaration of Helsinki.

Table 1 Patient clinical characteristics

\begin{tabular}{lcr}
\hline Characteristic & $\begin{array}{l}\text { No. of patients } \\
(N=246)\end{array}$ & $\%$ \\
\hline Age & & 100 \\
$\quad$ Median, 64.00 & 246 & \\
Mean, 62.44 \pm 10.01 & & \\
Gender & 52 & 21.1 \\
Female & 194 & 78.9 \\
Male & & \\
Tobacco & 65 & 26.4 \\
Non-smoker & 181 & 73.6 \\
Smoker/ex-smoker & & \\
Histologic type & 92 & 37.4 \\
NSCLC epidermoid & 151 & 61.4 \\
NSCLC non-epidermoid & 3 & 1.2 \\
Others & & \\
Stage & 14 & 5.7 \\
I & 17 & 6.9 \\
II & 125 & 36.6 \\
III & 90 & \\
IV & & \\
\hline
\end{tabular}


PCR-RFPL assay for detection of RAD51 G135C polymorphism

For detection of the RAD51 G135C polymorphism, we used polymerase chain reaction-restriction fragment length polymorphism (PCR-RFLP) according to a previously published protocol [24]. The PCR amplification was performed by using the following primers: forward ( $5^{\prime}$ TGGG AACTGCAACTCATCTGG-3') and reverse (5' GCGC TCCTCTCTCCAGCAG-3'). Conditions for PCR were an initial denaturation at $95^{\circ} \mathrm{C}$ for $5 \mathrm{~min}$, followed by 35 cycles at $94^{\circ} \mathrm{C}$ for $1 \mathrm{~min}, 53^{\circ} \mathrm{C}$ for $30 \mathrm{~s}$ (annealing temperature), $72^{\circ} \mathrm{C}$ for $1 \mathrm{~min}$, and ending with $72^{\circ} \mathrm{C}$ for $10 \mathrm{~min}$. The resulting $157-$ bp product was incubated at $37^{\circ} \mathrm{C} / 12-$ $16 \mathrm{~h}$ (overnight) with $1 \mathrm{U}$ of the restriction enzyme MvaI (Fermentas, ER0551). The restriction fragments were then visualized by $4 \%(\mathrm{p} / \mathrm{v})$ agarose gel electrophoresis, with ethidium bromide staining. Three types of band patterns were obtained: will type homozygote $(\mathrm{G} / \mathrm{G})$, two bands corresponding to 71 and $86 \mathrm{bp}$; heterozygote $(\mathrm{C} / \mathrm{G})$, three bands corresponding to 157,86 and $71 \mathrm{bp}$; and polymorphic homozygote (C/C), only one band with 157 bp (Fig. 1).

\section{Statistical analysis}

Analysis of data was performed using the computer software Statistical Package for Social Sciences (SPSS) for Windows (version 17.0). Differences in proportions were evaluated by the $\chi^{2}$ test.

The probabilities of survival were calculated, and the means and life tables were computed using the productlimit estimate of Kaplan and Meier. The curves were analysed by the Breslow (generalized Wilcoxon) test, a statistical test for equality of survival distributions. A level of $P<0.05$ was considered statistically significant. Survival

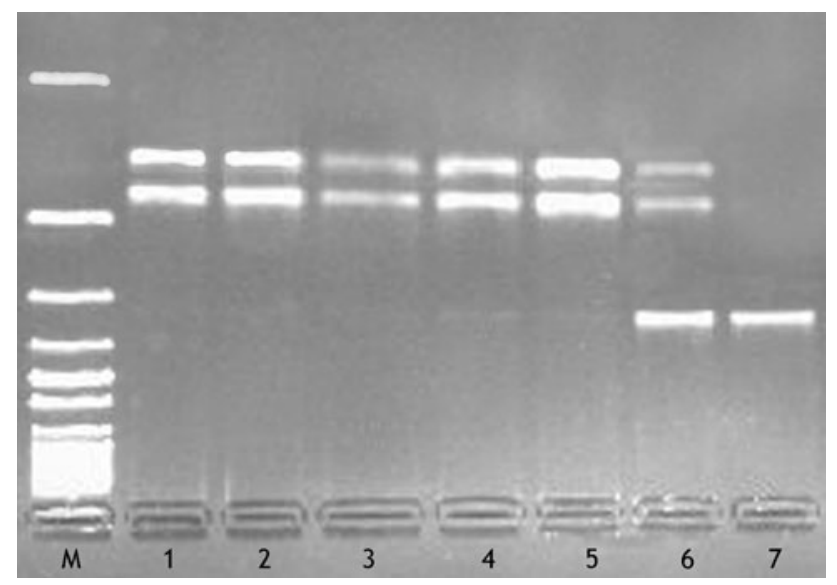

Fig. 1 Analysis of the RAD51 G135C polymorphism genotypes: $M, 50$ bp ladder; lanes 1, 2, 3, 4, and 5 homozygote GG; lanes6 heterozygote GC; and lane 7 polymorphic homozygote CC duration was defined as the time between diagnosis and either death or time of the last clinical evaluation of the patient.

\section{Results}

We analysed RAD51 G135C polymorphism genotypes using the PCR-RFLP methodology. The genotype frequencies observed were $85.4 \%$ for GG homozygous genotype, $13.8 \%$ for $\mathrm{CG}$ heterozygous genotype and $0.8 \%$ for $\mathrm{CC}$ homozygous genotype. There were no statistically significant differences between the groups of NSCLC patients with the different genotypes regarding tumour stage $(p=0.232)$ (Table 2).

Concerning the overall survival rates found using Kaplan-Meier methodology (Fig. 2), we observed that the mean survival rates were statistically different according to the patient's genotypes. The group of patients carrying the $\mathrm{C}$ allele presented a higher mean survival rate than the other patients (56.0 months vs. 41.7 months; $p=0.024)$. Thus, individuals with $\mathrm{CC} / \mathrm{GC}$ genotypes showed a higher overall survival, conferring a better prognosis for $\mathrm{C}$ allele carrier patients. Moreover, regarding smoking history, our results demonstrate that overall survival time differed significantly according to the patient's genotypes in smoker and exsmoker individuals $(p=0.034)$. Patients carrying $\mathrm{C}$ allele presented a higher survival rate, comparing with the other patients (56.4 months vs. 44.7 months, $p=0.034$ ) (Fig. 3a). No statistically significant differences were found in the genotype frequencies and overall survival rate among nonsmoker NSCLC patients ( $p=0.413$ ) (Fig. 3b).

\section{Discussion}

Lung cancer is one of the most common causes of cancerrelated death. Non-small cell lung cancer accounts for $75-85 \%$ of all histologic types of lung cancer. Despite

Table 2 Genotype frequencies of polymorphism in $R A D 51$ gene in NSCLC patients according tumour stage (Pearson $\chi^{2}$ test)

\begin{tabular}{|c|c|c|c|c|c|c|c|}
\hline & \multicolumn{6}{|c|}{ G135C polymorphism } & \multirow[t]{3}{*}{$P$} \\
\hline & \multicolumn{2}{|c|}{$\mathrm{CC}$} & \multicolumn{2}{|l|}{ GG } & \multicolumn{2}{|c|}{ GC } & \\
\hline & $N$ & $\%$ & $N$ & $\%$ & $N$ & $\%$ & \\
\hline \multicolumn{8}{|l|}{ Stage } \\
\hline I & 0 & 0 & 10 & 71.4 & 4 & 28.6 & 0.232 \\
\hline II & 0 & 0 & 14 & 82.4 & 3 & 17.6 & \\
\hline III & 0 & 0 & 106 & 84.8 & 19 & 15.2 & \\
\hline IV & 2 & 2.2 & 80 & 89.9 & 8 & 8.9 & \\
\hline Total & 2 & & 210 & & 34 & & 246 \\
\hline
\end{tabular}




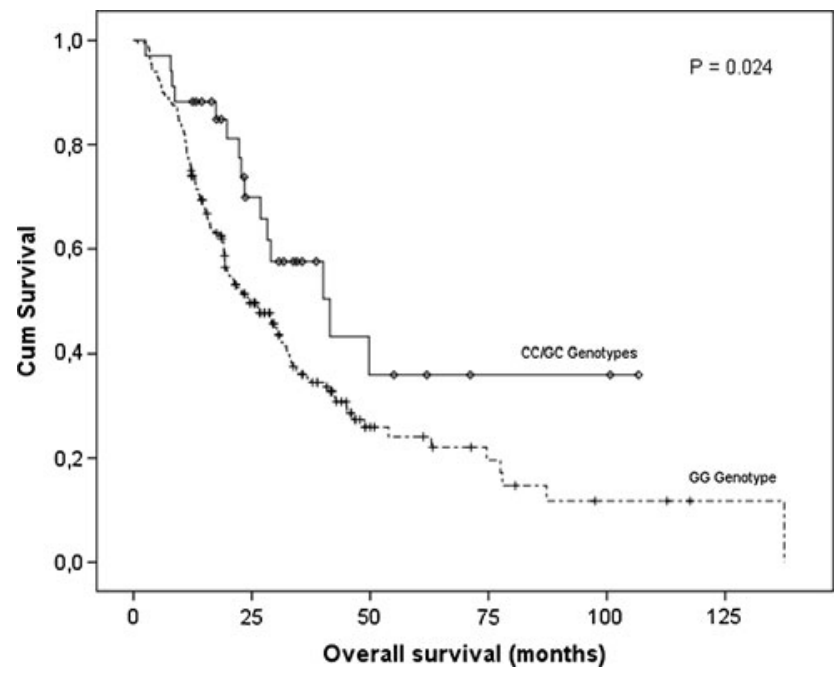

Fig. 2 Overall survival by Kaplan-Meier curves and Breslow test of NSCLC patients according to RAD51 G135C genotypes
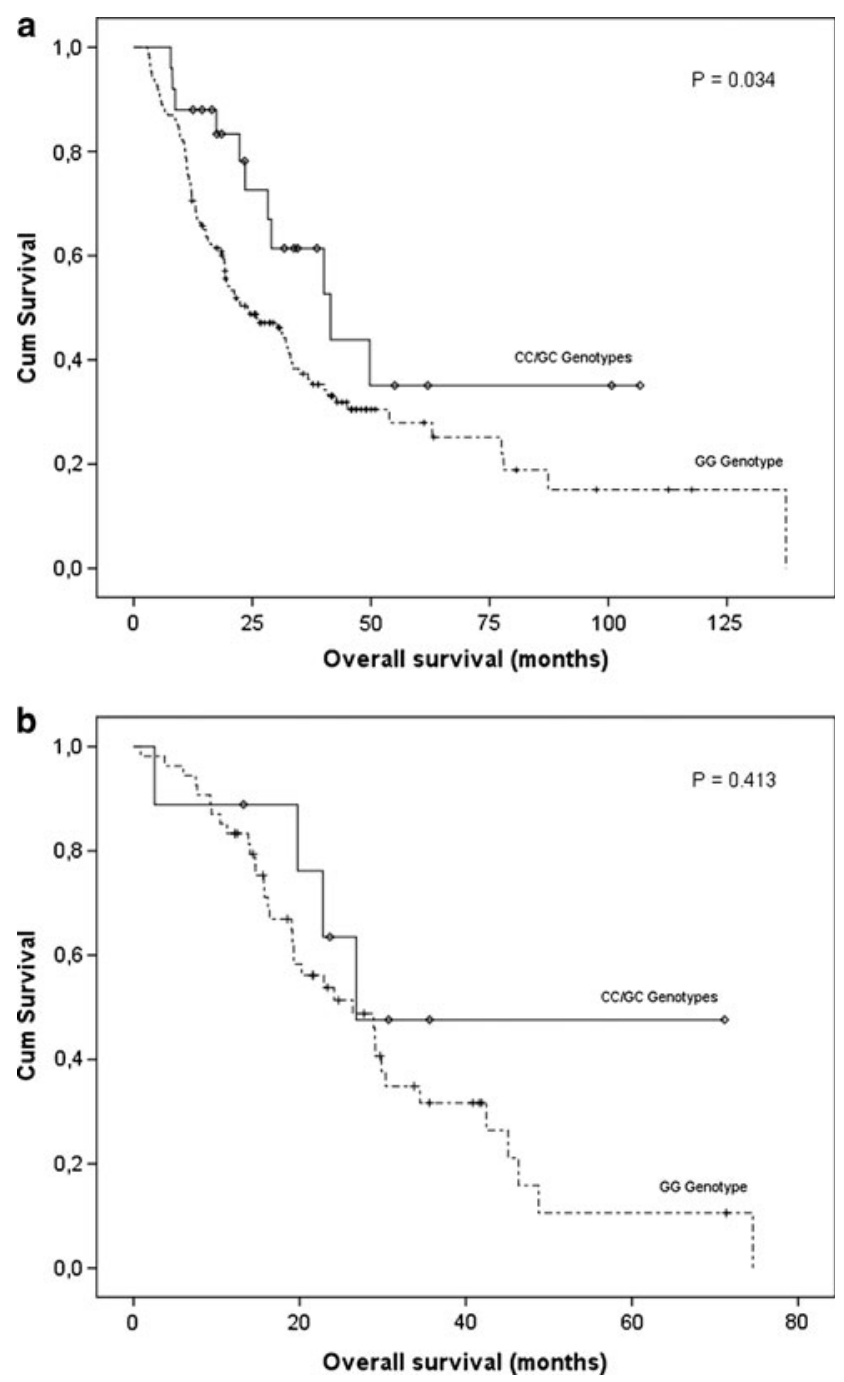

Fig. 3 Overall survival by Kaplan-Meier curves and Breslow test of NSCLC patients according to RAD51 genotypes and smoking history. a Smoker and ex-smoker NSCLC patients. b Non-smoker patients extensive preclinical and clinical research, the overall prognosis for patients with NSCLC remains poor, with a 5-year survival rate of only $14 \%$ [36].

Individual characteristics, such as genetic variations, are believed to be associated with an altered response to a chemotherapeutical treatment. Therefore, as predictive factors, it becomes important to study and understand the role of polymorphisms in cancer susceptibility and also in treatment response [27, 37].

The RAD51 gene is essential for survival in the absence of exogenous DNA damaging agents [39] and has a key role in the homologous recombination and repair of DNA [33]. Overexpression of human RAD51 protein has been observed in tumour cell lines of widely different origins [31] and increased levels of the protein have been correlated with elevated recombination rates [23]. It is also required for resistance to ionizing radiation $[5,28]$, and high levels of RAD51 have been correlated with resistance to chemotherapeutic agents $[12,35]$. According to previous studies in other tumour models, the study of RAD51 gene seems to be important for the prediction of treatment response with chemotherapeutic drugs [6].

Previous studies suggest that the aberrant overexpression of RAD51 protein could confer several advantages to tumour cells. First, the DNA repair function of RAD51 may protect cells from DNA damage and apoptosis. Second, overstimulation of homologous recombination and chromatid exchange mechanisms by RAD51 protein may contribute to genomic instability and genetic diversity of tumour cells [31]. The increased RAD51 protein expression leads to a perturbation of the cellular state of equilibrium, reflected in alterations of gene expression patterns detectable at the mRNA level [29].

There has been, however, little comprehensive examination of DNA repair processes, which might significantly contribute to the removal of therapeutic drugs, such as cisplatin, 5-FU and taxol and/or irradiation-induced DNA damage. In general, RAD51 expression seems to be correlated with resistance to therapeutic drugs [40]. Thus, a basal level of $R A D 51$ appears to be required for the processing of spontaneous DNA lesions. The constitutive overproduction of RAD51 in human tumours $[25,26]$ and in some transformed cell lines [31] may contribute for cytotoxic drug resistance induced by RAD51 in human cancers [14].

There are some studies that investigated the role of this polymorphism in the genetic susceptibility for development breast cancer [7, 16, 17, 20, 24], gastric cancer [30] and acute myeloid leukaemia [32, 42]. However, to the best of our knowledge, this is the first study evaluating the effect of the RAD51 G135C polymorphism in NSCLC patient survival.

Our results suggest that the RAD51 G135C 5'-UTR genotypes may provide additional prognostic information in NSCLC patients who underwent first line-based 
chemotherapy. In this study, our results demonstrate that the G135C C-allele is associated with a higher survival time, conferring a better prognosis than the GG genotype carrier patients (56.0 months vs. 41.7 months; $p=0.024)$. Thus, individuals carrying the $\mathrm{C}$ allele showed an overall survival of approximately 56 months after chemotherapy, compared with 42 months for individuals carrying the allele $\mathrm{G}$.

This study also indicates that the influence of RAD51 G135C polymorphism in treatment response of NSCLC patients seems to be modulated by smoking history. Our results demonstrate that smoker or ex-smoker patients carriers of $R A D 51 \mathrm{C}$-allele present a higher mean overall survival time, of 56 months comparing with 45 months for patients with GG genotype $(p=0.034)$. However, this association was not observed in non-smoker patients $(p=0.413)$.

RAD51 expression was identified as an independent predictor for tumour recurrence, as well as for tumour progression. These data demonstrate RAD51 expression as a clinically significant prognostic marker. Increased RAD51 protein levels could lead to uncontrolled recombination, genome instability, prevention of apoptosis, cell cycle arrest and increased resistance of tumours to radiotherapy and chemotherapy. As down-regulation of RAD51 protein by anti-sense oligonucleotides or small molecules sensitizes cells to DNA-damaging agents [28], this may be a promising strategy for tumour therapy [14].

Polymorphisms in untranslated regions have been shown to be important for cell proliferation, differentiation, tumour suppression, and metastasis suppression on several genes [9, 10]. For this reason, RAD51 G135C polymorphism at the $5^{\prime}$ UTR region can have an important role on protein expression and stability. As it is located in the $5^{\prime}$-untranslated region of the $R A D 51$ gene, this genetic variation could affect mRNA stability and/or translation efficiency, leading to altered product levels, which could alter the function of RAD51 protein [3]. Although some known regulatory elements are associated with $5^{\prime}$-UTRs [11], it is not clear how $135 \mathrm{C}$ polymorphism might affect gene function. Hasselbach et al. [13] suggested promoter activity enhancement by substituting $\mathrm{G}$ at the polymorphic position +135 , so that the $\mathrm{C}$-allele is associated with lower RAD51 expression levels.

Since increased RAD51 protein levels could lead to uncontrolled recombination, genome instability and increased tumour resistance to chemotherapy, we hypothesize that the $\mathrm{C}$-allele of $R A D 51$ polymorphism could derive lower protein expression levels, originating sensitized tumour cells, susceptible to chemotherapy treatment.

Thus, the presence of the G135C polymorphism may have a positive influence in treatment response, decreasing RAD51 expression levels in tumour cells and originating sensitized tumour cells, with normal cell proliferation, competent for apoptosis, with reduced recombination and presenting chemotherapy sensitivity.
To the best of our knowledge, this was the first study evaluating potential prognostic and predictive role of $R A D 51$ G135C polymorphism in NSCLC patients treated with combined platinum taxanes/gemcitabine first line chemotherapy.

We believe that RAD51 genotypes could be useful molecular markers for predicting the clinical outcome of NSCLC patients. Furthermore, in the attempt of optimizing responses, minimizing toxicities, and reducing the elevated costs associated with chemotherapy failure, the analysis of a wide range of molecular markers and genetic polymorphisms may contribute to the development of a pharmacogenomic profile, indicating the more appropriate chemotherapeutic protocol for each individual patient.

Acknowledgments The authors thank the Liga Portuguesa Contra o Cancro (Portuguese League against Cancer) - Centro Regional do Norte for their support. We also gratefully acknowledge for financial support of individual grant for Doctoral degree of the second author to Minister of Science, Technology and Superior Education-FCT (Fundação para a Ciência e Tecnologia: SFRH/BD/29898/2006).

Conflict of interest statement None.

\section{References}

1. Alberg AJ, Samet JM (2003) Epidemiology of lung cancer. Chest 123:21S-49S

2. Arnaudeau C, Lundin C, Helleday T (2001) DNA double-strand breaks associated with replication forks are predominantly repaired by homologous recombination involving an exchange mechanism in mammalian cells. J Mol Biol 307:1235-1245

3. Blasiak J, Przybylowska K, Czechowska A, Zadrozny M, Pertynski T, Rykala J, Kolacinska A, Morawiec Z, Drzewoski J (2003) Analysis of the G/C polymorphism in the 5'-untranslated region of the RAD51 gene in breast cancer. Acta Biochim Pol 50:249-253

4. Cohen V, Khuri FR (2004) Chemoprevention of lung cancer. Curr Opin Pulm Med 10:279-283

5. Collis SJ, Tighe A, Scott SD, Roberts SA, Hendry JH, Margison GP (2001) Ribozyme minigene-mediated RAD51 downregulation increases radiosensitivity of human prostate cancer cells. Nucleic Acids Res 29:1534-1538

6. Connell PP, Jayathilaka K, Haraf DJ, Weichselbaum RR, Vokes EE, Lingen MW (2006) Pilot study examining tumor expression of RAD51 and clinical outcomes in human head cancers. Int J Oncol 28:1113-1119

7. Costa S, Pinto D, Pereira D, Rodrigues H, Cameselle-Teijeiro J, Medeiros R, Schmitt F (2007) DNA repair polymorphisms might contribute differentially on familial and sporadic breast cancer susceptibility: a study on a Portuguese population. Breast Cancer Res Treat 103:209-217

8. Daboussi F, Dumay A, Delacote F, Lopez BS (2002) DNA doublestrand break repair signalling: the case of RAD51 post-translational regulation. Cell Signal 14:969-975

9. Facher EA, Becich MJ, Deka A, Law JC (1997) Association between human cancer and two polymorphisms occurring together in the p21Waf1/Cip1 cyclin-dependent kinase inhibitor gene. Cancer 79:2424-2429

10. Fan H, Villegas C, Huang A, Wright JA (1996) Suppression of malignancy by the $3^{\prime}$ untranslated regions of ribonucleotide reductase R1 and R2 messenger RNAs. Cancer Res 56:4366-4369 
11. Gray NK, Wickens M (1998) Control of translation initiation in animals. Annu Rev Cell Dev Biol 14:399-458

12. Hansen LT, Lundin C, Spang-Thomsen M, Petersen LN, Helleday $\mathrm{T}$ (2003) The role of RAD51 in etoposide (VP16) resistance in small cell lung cancer. Int J Cancer 105:472-479

13. Hasselbach L, Haase S, Fischer D, Kolberg HC, Sturzbecher HW (2005) Characterisation of the promoter region of the human DNA-repair gene Rad51. Eur J Gynaecol Oncol 26:589-598

14. Henning W, Sturzbecher HW (2003) Homologous recombination and cell cycle checkpoints: Rad51 in tumour progression and therapy resistance. Toxicology 193:91-109

15. Hoffman PC, Mauer AM, Vokes EE (2000) Lung cancer. Lancet 355:479-485

16. Jakubowska A, Gronwald J, Menkiszak J, Gorski B, Huzarski T, Byrski T, Edler L, Lubinski J, Scott RJ, Hamann U (2007) The RAD51 $135 \mathrm{G}>\mathrm{C}$ polymorphism modifies breast cancer and ovarian cancer risk in Polish BRCA1 mutation carriers. Cancer Epidemiol Biomarkers Prev 16:270-275

17. Jara L, Acevedo ML, Blanco R, Castro VG, Bravo T, Gomez F, Waugh E, Peralta O, Cabrera E, Reyes JM, Ampuero S, GonzalezHormazabal P (2007) RAD51 135G > C polymorphism and risk of familial breast cancer in a South American population. Cancer Genet Cytogenet 178:65-69

18. Jemal A, Murray T, Ward E, Samuels A, Tiwari RC, Ghafoor A, Feuer EJ, Thun MJ (2005) Cancer statistics, 2005. CA Cancer J Clin 55:10-30

19. Jemal A, Siegel R, Ward E, Murray T, Xu J, Thun MJ (2007) Cancer statistics, 2007. CA Cancer J Clin 57:43-66

20. Kadouri L, Kote-Jarai Z, Hubert A, Durocher F, Abeliovich D, Glaser B, Hamburger T, Eeles RA, Peretz T (2004) A singlenucleotide polymorphism in the RAD51 gene modifies breast cancer risk in BRCA2 carriers, but not in BRCA1 carriers or noncarriers. Br J Cancer 90:2002-2005

21. Karran P (2000) DNA double strand break repair in mammalian cells. Curr Opin Genet Dev 10:144-150

22. Khanna KK, Jackson SP (2001) DNA double-strand breaks: signaling, repair and the cancer connection. Nat Genet 27:247-254

23. Lambert S, Lopez BS (2000) Characterization of mammalian RAD51 double strand break repair using non-lethal dominant-negative forms. EMBO J 19:3090-3099

24. Levy-Lahad E, Lahad A, Eisenberg S, Dagan E, Paperna T, Kasinetz L, Catane R, Kaufman B, Beller U, Renbaum P, Gershoni-Baruch R (2001) A single nucleotide polymorphism in the RAD51 gene modifies cancer risk in BRCA2 but not BRCA1 carriers. Proc Natl Acad Sci USA 98:3232-3236

25. Maacke H, Jost K, Opitz S, Miska S, Yuan Y, Hasselbach L, Luttges J, Kalthoff H, Sturzbecher HW (2000) DNA repair and recombination factor Rad51 is over-expressed in human pancreatic adenocarcinoma. Oncogene 19:2791-2795

26. Maacke H, Opitz S, Jost K, Hamdorf W, Henning W, Kruger S, Feller AC, Lopens A, Diedrich K, Schwinger E, Sturzbecher HW (2000) Over-expression of wild-type Rad51 correlates with histological grading of invasive ductal breast cancer. Int J Cancer 88:907-913

27. Medeiros R, Pereira D, Afonso N, Palmeira C, Faleiro C, AfonsoLopes C, Freitas-Silva M, Vasconcelos A, Costa S, Osorio T, Lopes C (2003) Platinum/paclitaxel-based chemotherapy in advanced ovarian carcinoma: glutathione S-transferase genetic polymorphisms as predictive biomarkers of disease outcome. Int J Clin Oncol 8:156-161

28. Ohnishi T, Taki T, Hiraga S, Arita N, Morita T (1998) In vitro and in vivo potentiation of radiosensitivity of malignant gliomas by antisense inhibition of the RAD51 gene. Biochem Biophys Res Commun 245:319-324

29. Orre LM, Falt S, Szeles A, Lewensohn R, Wennborg A, Flygare J (2006) Rad51-related changes in global gene expression. Biochem Biophys Res Commun 341:334-342
30. Poplawski T, Arabski M, Kozirowska D, Blasinska-Morawiec M, Morawiec Z, Morawiec-Bajda A, Klupinska G, Jeziorski A, Chojnacki J, Blasiak J (2006) DNA damage and repair in gastric cancer-a correlation with the hOGG1 and RAD51 genes polymorphisms. Mutat Res 601:83-91

31. Raderschall E, Stout K, Freier S, Suckow V, Schweiger S, Haaf T (2002) Elevated levels of Rad51 recombination protein in tumor cells. Cancer Res 62:219-225

32. Rollinson S, Smith AG, Allan JM, Adamson PJ, Scott K, Skibola CF, Smith MT, Morgan GJ (2007) RAD51 homologous recombination repair gene haplotypes and risk of acute myeloid leukaemia. Leuk Res 31:169-174

33. Schmutte C, Tombline G, Rhiem K, Sadoff MM, Schmutzler R, von Deimling A, Fishel R (1999) Characterization of the human Rad51 genomic locus and examination of tumors with 15q14-15 loss of heterozygosity (LOH). Cancer Res 59:4564-4569

34. Shinohara A, Ogawa H, Matsuda Y, Ushio N, Ikeo K, Ogawa T (1993) Cloning of human, mouse and fission yeast recombination genes homologous to RAD51 and recA. Nat Genet 4:239-243

35. Slupianek A, Hoser G, Majsterek I, Bronisz A, Malecki M, Blasiak J, Fishel R, Skorski T (2002) Fusion tyrosine kinases induce drug resistance by stimulation of homology-dependent recombination repair, prolongation of $\mathrm{G}(2) / \mathrm{M}$ phase, and protection from apoptosis. Mol Cell Biol 22:4189-4201

36. Spira A, Ettinger DS (2004) Multidisciplinary management of lung cancer. N Engl J Med 350:379-392

37. Sullivan A, Syed N, Gasco M, Bergamaschi D, Trigiante G, Attard M, Hiller L, Farrell PJ, Smith P, Lu X, Crook T (2004) Polymorphism in wild-type p53 modulates response to chemotherapy in vitro and in vivo. Oncogene 23:3328-3337

38. Takahashi E, Matsuda Y, Hori T, Yasuda N, Tsuji S, Mori M, Yoshimura Y, Yamamoto A, Morita T, Matsushiro A (1994) Chromosome mapping of the human (RECA) and mouse (Reca) homologs of the yeast RAD51 and Escherichia coli recA genes to human (15q15.1) and mouse (2F1) chromosomes by direct Rbanding fluorescence in situ hybridization. Genomics 19:376-378

39. Tsuzuki T, Fujii Y, Sakumi K, Tominaga Y, Nakao K, Sekiguchi M, Matsushiro A, Yoshimura Y, Morita T (1996) Targeted disruption of the Rad51 gene leads to lethality in embryonic mice. Proc Natl Acad Sci USA 93:6236-6240

40. Vispe S, Cazaux C, Lesca C, Defais M (1998) Overexpression of Rad51 protein stimulates homologous recombination and increases resistance of mammalian cells to ionizing radiation. Nucleic Acids Res 26:2859-2864

41. Vispe S, Defais M (1997) Mammalian Rad51 protein: a RecA homologue with pleiotropic functions. Biochimie 79:587-592

42. Voso MT, Fabiani E, D'Alo F, Guidi F, Di Ruscio A, Sica S, Pagano L, Greco M, Hohaus S, Leone G (2007) Increased risk of acute myeloid leukaemia due to polymorphisms in detoxification and DNA repair enzymes. Ann Oncol 18:1523-1528

43. Wick W, Petersen I, Schmutzler RK, Wolfarth B, Lenartz D, Bierhoff E, Hummerich J, Muller DJ, Stangl AP, Schramm J, Wiestler OD, von Deimling A (1996) Evidence for a novel tumor suppressor gene on chromosome 15 associated with progression to a metastatic stage in breast cancer. Oncogene 12:973-978

44. Yamamoto A, Taki T, Yagi H, Habu T, Yoshida K, Yoshimura Y, Yamamoto K, Matsushiro A, Nishimune Y, Morita T (1996) Cell cycle-dependent expression of the mouse Rad51 gene in proliferating cells. Mol Gen Genet 251:1-12

45. Young RP, Hopkins RJ, Hay BA, Epton MJ, Mills GD, Black PN, Gardner HD, Sullivan R, Gamble GD (2009) Lung cancer susceptibility model based on age, family history and genetic variants. PLoS ONE 4:e5302

46. Yuan SS, Chang HL, Lee EY (2003) Ionizing radiation-induced Rad51 nuclear focus formation is cell cycle-regulated and defective in both $\operatorname{ATM}(-/-)$ and c-Abl(-/-) cells. Mutat Res 525:85-92 